\title{
An Opportunistic Routing Scheme Based on Social Relations in Delay-Tolerant Networks
}

\author{
Chan-Myung $\mathrm{Kim}^{+} \cdot$ In-SeoK Kang ${ }^{\text {t+ }} \cdot$ Young-Jun $\mathrm{Oh}^{+++} \cdot$ Youn-Hee $\mathrm{Han}^{++++}$
}

\begin{abstract}
Delay-Tolerant Network employs message forwarding based on a Store, Carry and Forward method to conquer no guarantee of continue connectivity. For this reason, a lot of DTN routing scheme have been proposed recently. message forwarding is an important research issue in delay-tolerant network and In this paper, we propose a ef $\iota$ ficiency DTN routing scheme using node's social relation and expanded Ego-network betweenness centrality. Our simulation results show that it is more efficient to message delivery cost than Epidemic routing, Friendship routing while it has a little performance degradation of message delivery ratio.
\end{abstract}

Keywords : Delay Tolerant Network, Social Network, Expanded Ego-Network

\section{지연 감내 네트워크에서 사회관계기반 기회적 라우팅 기법}

\author{
김 찬 명 $\cdot$ 강 인 석 ${ }^{+\dagger} \cdot$ 오 영 준 ${ }^{+\dagger+} \cdot$ 한 연 희 $^{+++}$
}

\section{요 약}

지연 감내 네트워크는 지속적인 연결이 보장되지 않고 저장(Store), 운반(Carry), 전달(Forward) 방식의 메시지 전달을 사용 하는 네트워크 이다. 이러한 지연 감내 네트워크에서 메시지 전달은 중요한 연구 이슈이며, 최근 많은 라우팅 기법들이 제안되었다. 본 논문에서는 노드들의 사회관계와 확장 매개 중심도를 이용하여 효율적인 지연 감내 네트워크에서 라우팅 기법을 제안한다. 시뮬레이션 결과를 통해 Epidemic routing, Friendship routing에 비해 적은 메시지 전달 성공률차이를 유지하며, 메시지 전달 비용에는 효율적임을 보인다.

키워드 : 지연 감내 네트워크, 사회관계망, 확장 자아 네트워크

\section{1. 서 론}

최근 지연 감내 네트워크 (Delay-Tolerant Network, 이 하 DTN)에서 임의의 메시지를 목적지 노드까지 전달하는 기회적 라우팅 (Opportunistic Routing) 기법들이 제안 되고 있다 $[1,3,4]$. 지연 감내 네트워크에서는 각 메시지들을 저 장(Store), 운반(Carry), 전달(Forward)이라는 방식을 통해 목적지 노드에게 전달한다. 네트워크에 존재하는 노드는 이 동성을 가지고 끊임없이 움직이며 다른 노드와 접촉을 하여 메시지를 서로 주고받는다. 저장(Store)은 지연 감내 네트워 크를 지원하기 위해 각 노드 내부에 새롭게 구성되는 Bundle

\footnotetext{
※ 이 논문은 2013년도 정부(교육부)의 재원으로 한국연구재단의 지원을 받 아 수행된 기초연구사업(NRF-2013R1A1A2010050)과 지식경제부와 한국 산업기술진흥원의 전략기술인력양성사업의 지원을 받아 수행되었음.

† 정 회 원: 한국기술교육대학교 컴퓨터공학과 박사과정

†† 준 회 원: 삼성전자 무선사업부 연구원

††† 비 회 원 : 한국기술교육대학교 컴퓨터공학과 박사과정

†ㅎ 종시회워 : 한국기술교육대학교 컴퓨터공학부 교수

논문접수:2013년 10월 31일

수 정 일 : 1 차 2013 년 12 월 30 일

심사완료 : 2013년 12월 31일

* Corresponding Author: Youn-Hee Han(yhhan@koreatech.ac.kr)
}

Layer에 메시지를 저장하는 기능을 지칭하며, 운반(Carry) 동작은 노드가 전달받은 메시지를 가지고 이동을 하는 동작 을 지칭한다. 마지막으로 전달(Forward)은 이동성을 가진 노드가 다른 노드와 접촉할 시 메시지를 전송하는 동작을 지칭한다 [1].

최근 연구된 DTN 라우팅 기법들을 분석해보면 각 제안 기법별로 사용한 네트워크 그래프가 다름을 알 수 있다[2]. 처음 제안되었던 Epidemic Routing[3]의 경우 하위 계층의 통신 범위 내에 상대방이 존재하면 링크(link)를 형성하여 구성하는 무선 네트워크 그래프(Wireless Network Graph) 를 사용하였으며, 그 이후 제안된 PRoPhet Routing[4]은 무 선 통신 범위 안에 들어온 두 노드들에 대해 '접촉 (Contact)' 이라는 표현으로 그 두 노드들의 행동양식을 정의하고 접촉 네트워크 그래프(Contact Network Graph)를 구성하여 라우 팅 기법을 제안하였다. 한편, BUBBLE Rap Routing[5]의 경우 접촉 그래프를 누적하여 접촉이 상대적으로 많은 노 드들끼리 링크를 연결하여 구성한 사회관계 네트워크 그래 프(Social Network Graph)를 사용하였다. 최근 제안되었던 Friendship Routing[6]도 역시 사회관계 네트워크 그래프를 
사용하여 라우팅 기법을 제안하였다. 이와 같이 DTN의 최 근 연구들을 노드들의 접촉 관계 누적 정보를 기반으로 하 여 일종의 사회관계성을 부여하고 이를 분석하여 임의의 메 시지를 목적지 노드에게 라우팅하는 기법을 제안하고 있다.

사회관계망 분석 기법 중에는 노드 중심성(Centrality)을 분석하는 기법이 존재하며, 네트워크상에서 각 노드는 자신 의 중심성을 연결 중심도(Degree Centrality), 매개 중심도 (Betweenness Centrality)와 같은 방식으로 산출할 수 있다 [7, 8]. 노드의 중심성이란 네트워크에 존재하는 노드들 중에 서 중요도가 높은 노드를 나타내며, 본 논문에서는 메시지 라우팅의 매개 역할을 잘 할 수 있는 노드를 알아낼 수 있 는 매개 중심도를 산출하여 라우팅 기법에 사용한다. 또한 네트워크의 각 노드는 전체 네트워크를 추정할 수 없기 때 문에 각 노드마다 자신의 지역 정보만을 활용하여 구성하는 자아 네트워크(Ego Network)를 확장한 네트워크인 확장 자 아 네트워크(Expanded Ego Network)[9, 10]를 이용하여 각 노드 가 스스로 확장 자아 매개 중심도(Expanded Ego Betweenness Centrality)를 산출하여 메시지 전달 기법에 사용한다.

본 논문의 구성은 다음과 같다. 2장에서는 지금까지 제안 된 대표적인 DTN 라우팅 기법들의 특징을 소개한다. 3장에 서는 노드들의 사회관계망 구성 방법 및 확장 자아 매개 중 심도를 이용한 메시지 전달 기법을 제안한다. 4장에서는 실 험환경을 소개하고 라우팅 기법을 비교하기 위해 주어진 평 가지표를 기준으로 성능을 비교 분석한다. 마지막으로 5장 에서는 본 논문의 결론과 향후 연구 방향에 대해 설명한다.

\section{2. 관련 연구}

$\mathrm{DTN}$ 에서의 라우팅 기법의 최초 방법으로 알려진 Epidemic Routing[3, 11]은 기본적으로 플러딩(flooding) 기 법을 사용하여 메시지를 주변 노드들에게 전파시키면서 목 적지 노드까지 전달하는 라우팅 기법이다. 서로 다른 두 노 드 $\mathrm{A}, \mathrm{B}$ 가 그들 간의 통신 반경 범위에 들어오게 되면 그 두 노드는 자신들이 가지고 있는 메시지 정보를 교환하여 두 노드 각자가 보유하고 있는 메시지를 비교하게 된다. 이 과정을 통해 자신이 지니고 있는 메시지를 상대방 노드가 보유하고 있지 않다는 것을 알게 되면 자신이 지니고 있는 해당 메시지를 전달해준다. 이러한 방식으로 매번 통신 반 경에 들어오는 노드들에게 메시지를 전달하여 목적지 노드 까지 메시지를 전달한다. 이러한 Epidemic Routing은 메시 지 전달 성공률은 매우 높지만, 통신이 가능한 노드 모두에 게 메시지를 전달하기 때문에 메시지 전달 비용이 증가할 수밖에 없다.

PRoPhet Routing[4]은 통신 범위 안에 들어온 두 노드들 에 대해 '접촉 (Contact)'이라는 표현으로 그 두 노드들의 행 동양식을 정의하고, 접촉하는 노드들과의 접촉 정보를 통해 임의의 노드에서 다른 노드까지 메시지가 전달될 수 있는 확률 값을 각 노드들이 유지하도록 한다. 또한, 이러한 메시 지 전달 확률 값을 이용하여 높은 전달 확률 값을 가지고 있는 노드에게 메시지를 전달하는 라우팅 기법을 제시한다. PRoPhet Routing 은 Epidemic Routing처럼 무분별하게 메시 지를 복사하여 다른 노드에게 전달하는 것이 아니라 자신이
가지고 있는 다른 노드로의 메시지 전달 확률 값을 이용하 여 메시진 전달을 효율적으로 수행한다.

BUBBLE Rap Routing[5]은 각 노드들과 그들 간의 접촉 정보를 기반으로 사회관계망을 구성하고 각 노드들에게 순 위를 부여하여 이 순위를 기반으로 메시지를 전달하는 라우 팅 기법이다. BUBBLE Rap Routing에서는 각 노드들에게 연결 중심도를 이용하여 중요도 순위를 부여한다. 각 노드 들은 이러한 순위 정보를 지니면서 이동을 하다가 임의의 순간에 다른 노드와 접촉하게 되면, 자신의 순위 및 접촉한 노드의 순위를 비교하여 접촉한 노드의 순위가 높다면 메시 지를 전달하는 방식으로 동작한다. 이렇게 새롭게 접촉한 노드들의 정보는 사회관계망을 동적으로 구성하기 위한 정 보로 계속 활용된다. 또한, 전체 사회관계망 내에서 활발한 접 촉관계를 보이는 일부 노드들의 그룹을 커뮤니티(Community) 로서 정의하고 메시지가 전달되면서 목적지 노드가 속한 커 뮤니티 내의 임의의 노드에게 그 메시지가 전달되면 커뮤니 티 내부에서의 연결 중심도 순위를 활용하여 최종 목적지 노드까지 메시지를 전달한다. 하지만, 본 기법에서는 중요도 가 상대적으로 낮은 노드로의 메시지 전달이 잘 되지 않는 다는 단점이 있다.

Friendship Routing[6]은 노드들 간의 접촉정보를 이용하 여 노드 사이의 사회관계망 링크에 가중치(Weight)를 부여 하고 그 가중치 값을 활용하여 메시지를 전달하는 라우팅 기법이다. 노드 사이 링크에 대한 가중치 값은 노드들 간의 접촉 횟수와 접촉이 지속되는 시간을 통해 산출된다. 이처 럼 각 노드는 접촉하는 모든 노드와의 가중치 값을 생성하 며, 임의의 노드가 접촉하는 노드들이 다시 접촉하는 노드 들까지의 가중치 정보를 통해 아직 접촉이 한 번도 없는 노 드까지도 가상의 가중치 값을 산출한다. 이러한 가중치 값 은 사회관계망을 구성할 때 사용하거나 메시지를 전달할 경 우 사용하게 된다. 사회관계망을 구성할 시에는 미리 정해 놓은 임계값보다 큰 가중치를 지니고 있는 노드들로만 구성 하며, 메시지의 전달 시에는 현재 접촉한 노드가 자신의 사 회관계망에 포함될 경우 최종 목적지 노드와의 가중치를 비 교하여 접촉한 노드와 목적지 노드 사이의 가중치가 크다면 메시지를 전달한다.

BUBBLE Rap Routing과 Friendship Routing과 같이 최 근 사회관계망을 DTN 라우팅 기법에 적용하는 연구가 활 발히 진행되어 왔지만 여전히 메시지 전달 성공률 및 메시 지 전달 비용 면에서 더욱 그 성능을 향상시킬 필요가 있다. 본 논문에서는 Friendship Routing과 비슷하게 노드들의 접 촉 정보를 기반으로 가중치를 지닌 사회관계망을 구성하는 새로운 방법을 제안하고, 그러한 가중치 및 노드들의 확장 자아 매개 중심도를 활용하여 메시지 전달에 있어서 그 효 율성을 더욱 높일 수 있는 라우팅 기법을 제안한다.

\section{3. 제안하는 효율적인 라우팅 기법}

\subsection{DTN (Delay-Tolerant Networks) 환경 및 접촉(Contact)의 정의}

본 논문에서는 이동성을 지닌 다수의 노드로 이루어져 네 트워크 위상(Topology)이 동적으로 변하는 $\mathrm{DTN}$ 을 가정한 
다. $r$ 을 임의의 노드에 대한 통신 범위라고 할 때, 노드 $v_{i}$ 는 거리 $d \leq r$ 에 있는 노드에게 메시지 전달이 가능하다. 이 때 메시지간의 충돌은 발생하지 않으며 각 메시지는 성 공적으로 한 번에 전달 가능하다고 가정한다. 임의의 노드 $i$ 와 노드 $j$ 의 거리가 $r$ 이하이고 노드 $j$ 가 브로드캐스트한 Hello 메시지를 노드 $i$ 가 수신했을 때 노드 $i$ 와 노드 $j$ 가 접촉(Contact)했다고 판단한다. 이후, 노드 $i$ 는 노드 $j$ 가 주 기적으로 보내는 Hello 메시지를 지속적으로 수신할 것이며, 만약 미리 정해놓은 수 (예를 들어, 3번)만큼의 Hello 메시 지를 수신하지 못할 경우 노드 $i$ 는 노드 $j$ 가 떠났다(Leave) 고 판단한다. 만약 $\alpha$ 가 임의의 노드와 접촉한 시각이고 $\beta$ 가 접촉했던 노드가 떠난 시각이라면 $\beta-\alpha$ 을 그 노드와의 접촉 시간(Contact Duration)이라고 정의한다.

\section{2 노드의 사회관계망 구성 전략}

본 논문에서 제안하는 DTN 라우팅 기법은 Friendship Routing과 비슷하게 각 노드들이 스스로 자신만의 사회관계 망을 구축한다. 한편, 임의의 노드가 다른 노드와 접촉을 하 였을 때 그 접촉한 노드가 자신의 사회관계망에 속에 있을 때만 자신의 버퍼에 있는 메시지를 그 접촉 노드에게 전달 을 시도하는 방식이다. 본 장에서는 이러한 메시지 전달 대 상으로 선정될 수 있는 노드들로 구성되는 사회관계망을 구 성하는 방안을 제시한다.

1) 노드간의 접촉 정보 관리 및 사회관계망 구성

위 각 노드들은 자신만의 사회관계망을 구성하기 위하여 다른 노드들과의 접촉기록을 지속적으로 저장하고, 자신과 다른 노드와의 사회관계망 구성에 필요한 링크 및 가중치 (weight)을 형성한다. 좀 더 구체적으로, 임의의 노드 $i$ 를 기준으로 다른 노드 $j$ 와의 가중치 값이 미리 정해 놓은 임 계값보다 클 경우 노드 $i$ 와 노드 $j$ 사이에 링크가 형성되 며 이는 곧 노드 $i$ 의 사회관계망에 노드 $j$ 가 포함됨을 의 미한다.

이러한 링크 가중치를 산출하기 위해 각 노드는 다른 노 드와의 접촉 기록을 단위 시간마다 저장 및 관리한다. 또한, 접촉 윈도우(Contact Window) 및 접촉 윈도우 크기(Contact Windows Size, 이하 $W_{s}$ )를 미리 할당하여 이러한 접촉 윈 도우내에 존재하는 최근의 접촉 시간들을 누적하여 링크 가 중치를 계산한다. 시간의 흐름에 따라 접촉 윈도우는 $\mathrm{TCP}$ 의 슬라이딩 윈도우와 같이 단위 시간마다 슬라이딩 하여 최신의 접촉 정보로 갱신되고 접촉 윈도우 크기보다 오래된 접촉 정보를 삭제한다. 각 노드들은 이동을 하면서 다른 노 드들로부터 받는 Hello 메시지를 기반으로 3.1절에서 설명한 방법대로 접촉 시간 정보를 기록한다.

Fig. 1. 은 예를 들어 단위 시간이 1 초이고 접촉 윈도우 크기 $W_{s}$ 가 600 초일 때 해당 접촉 윈도우 내의 노드 $i$ 가 노 드 $j$ 를 만난 접촉 정보를 보여준다. 또한 최근의 600 초 동 안 노드 $i$ 는 노드 $j$ 와 총 5 번의 접촉이 있었으며 각 접촉마 다의 접촉 시간을 모두 더한 누적 접촉 시간은 311초임을 알 수 있다. i

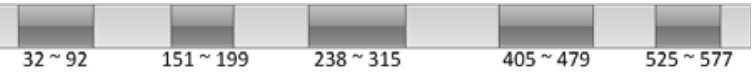

Fig. 1. Node $i$ 's contact history for node $j$ (unit-time $=1 \mathrm{sec}$., $W_{s}=600 \mathrm{sec}$.)

위에서 설명한 접촉 정보를 바탕으로 본 논문에서는 Friendship Routing에서 제시한 다음 식 (1)을 이용하여 임 의의 노드 $i$ 는 노드 $j$ 와의 가중치를 산출한다.

$$
\text { Weight }_{i, j}=\frac{W_{s}}{\int_{t=0}^{W_{s}} f(t) d t}
$$

위 식 (1)에서 $f(t)$ 는 노드 $i$ 가 노드 $j$ 와 접촉하지 않은 시각 $t$ 이후에 접촉을 할 때까지 남은 시간을 나타낸다. 예 를 들어, 접촉 윈도우 크기 $W_{s}$ 가 10 이고, 노드 $i$ 가 노드 $j$ 와 접촉 윈도우 내에서 $t=5$ 일 때부터 $t=8$ 까지 3 초간 접촉 하지 않았다면 $3,2,1$ 이 각각 $f(t)$ 가 되어 식(1)에 의하여 Weight $_{i, j}$ 값은 $10 /(3+2+1)=5 / 3$ 값이 할당된다. 결과적으 로 노드간 접촉을 하지 않는 시간이 적을수록 가중치는 늘 어나게 된다.

임의의 노드 $i$ 는 지속적으로 임의의 새로운 노드 $j$ 와 접 촉을 할 때 마다 위에서 설명한 방법대로 $W_{e i g h t}$ 값을 갱 신하고 그 Weight $_{i, j}$ 값이 미리 정해 놓은 임계값 $T_{h}$ 보다 크 면 해당 노드를 자신의 사회관계망 $S N_{i}$ 내의 한 노드로 설 정하고 그 노드로의 새로운 링크의 가중치로 $W_{e i g h t}$ 를 설 정한다. 또한, 노드 $i$ 의 $S N_{i}$ 에 편입시킬 새로운 노드로서 전 통적인 사회관계망 분석에서 활용하는 $\mathrm{FoF}$ (Friends of Friends) 개념을 활용하여 노드 $i$ 의 사회관계망 $S N_{i}$ 내에 노드 $j$ 가 있고 노드 $j$ 의 사회관계망 $S N_{j}$ 내에 노드 $k$ 가 있 다면 노드 $i$ 의 사회관계망인 $S N_{i}$ 에 노드 $k$ 를 포함시킨다. 즉, Fig. 2. 에서와 같이 노드 $i$ 의 $S N_{i}$ 에는 노드 $a, b, c, d, e, j$ 뿐만 아니라 $S N_{j}$ 내의 $x, y, z$ 도 포함된다. 이와 같은 방식으 로 구성되는 사회관계망에 포함되는 노드의 수는 기존 Friendship Routing 기법에서 제시하는 사회관계망에 포함 되는 노드 수보다 다소 줄어든다. 따라서, 임의의 노드가 다 른 노드를 만났을 경우 그 노드를 메시지 전달 대상으로 선 정할 가능성도 다소 줄어들기 때문에 메시지 전달 비용 측 면에서 이점이 있다. 이러한 전략은 또한 메시지 전달 성공 률 면에서는 좋지 않은 영향을 주겠지만 이후 설명할 효율 적인 메시지 전달 전략을 통해 이러한 단점을 어느 정도

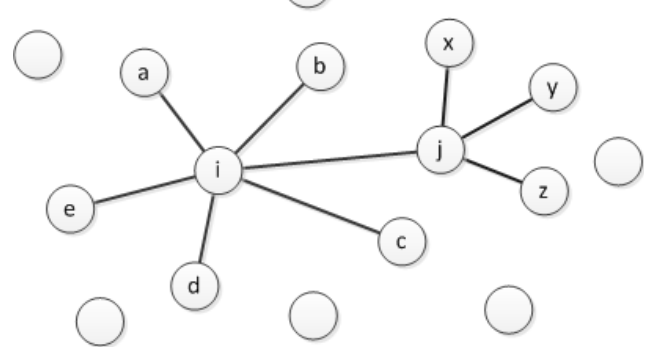

Fig. 2. $S N_{i}$ of Node $i\left(S N_{i}=a, b, c, d, e, j, x, y, z\right)$ 
극복할 수 있다.

요약하여, 임의의 노드 $i$ 의 사회관계망 $S N_{i}$ 에 존재하는 노드들의 집합을 $V_{i}$, 링크의 집합을 $E_{i}$, 노드 $i$ 의 1-hop 이 웃 노드를 $N_{i}$ 라고 정의할 때, $S N_{i}$ 의 구성은 매 단위 시간 마다 다음 Table 1. 에서 제시된 절차에 의해 관리된다.

\section{Table 1. Social network construction procedure for a node $i$}

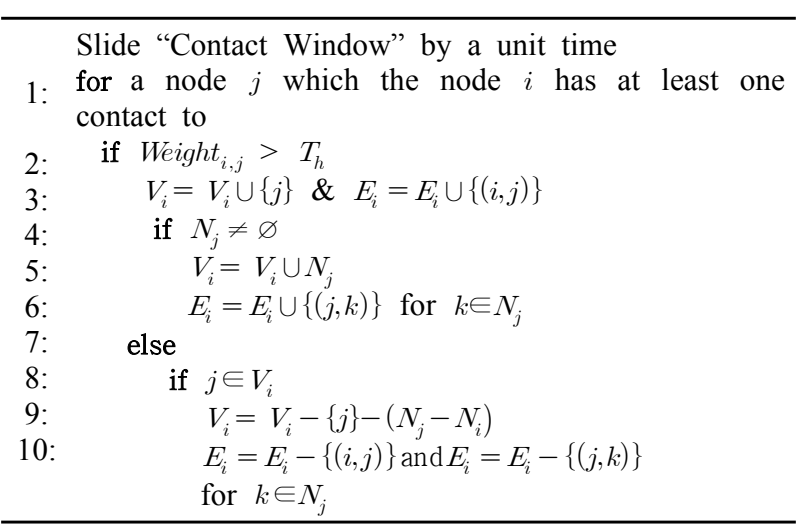

2) 확장 자아 매개 중심도

전통적으로 매개 중심도는 사회관계망 내에서 각 노드가 메시지 전달 매개역할을 얼마나 잘 수행할 수 있는지에 대 한 지표로 활용되어 왔다[7,8]. 본 논문에서는 메시지 전달 성공률 및 효율을 높이기 위하여 매개 중심도를 메시지 라 우팅 전략에 활용한다. 임의의 주어진 사회관계망에서 임의 의 노드 $i$ 에 대한 매개 중심도는 수식 (2)와 같다.

$$
C_{B}(i)=\sum_{\substack{s \neq i \neq t \in v, s<t}} \frac{\rho_{s t}(i)}{\rho_{s t}}
$$

위 식 (2)에서 $V$ 는 모든 노드의 집합이며 $\rho_{s t}$ 는 노드 $s$ 와 $t$ 사이의 최단경로 (shortest path) 개수이며, $\rho_{s t}(i)$ 는 노드 $s$ 와 $t$ 사이의 최단경로 중에서 노드 $i$ 를 통과하는 것들의 개 수이다. 위 식에 따르면 임의의 노드 $i$ 의 매개 중심도는 네 트워크에 존재하는 임의의 두 노드 사이의 최단 경로가 노 드 $i$ 를 많이 지나갈수록 높아진다. 즉. 두 개의 서로 다른 노드들끼리 메시지를 교환할 때 그 메시지는 매개 중심도가 높은 노드를 지나갈 확률이 높아진다. 하지만, 위 식 (2)는 전통적인 사회관계망에서 활용되어 왔던 매개 중심도이며 중앙 집중형 서버에서 전체 네트워크 구조를 우선 파악하여 계산하는 방식이기 때문에 완전 분산형으로 라우팅이 운영 되는 DTN 환경에 활용하기에 부적합하다. 그래서, 본 논문 에서는 DTN 환경에 좀 더 알맞도록 매개 중심도를 다소 변 형한 “확장 자아 네트워크(Expended Ego Network)” 및 “확장 자아 매개 중심도(Expanded Ego Betweenness Centrality)"를 활용한다. 확장 자아 네트워크 및 확장 자아 매개 중심도는 본 논문의 선행연구로서 $[9,10]$ 에 자세하게 제안되어 있다.

기존 사회관계망 분석에서 오랫동안 사용해 온 “자아 네 트워크 (Ego Network) [12, 13]”는 노드 $i$ 로부터 반경 (radius) 1-hop 내에 존재하는 노드들 및 그들 간에 연결된 간선들로 이루진 네트워크이다 (Fig. 3. (a) 참조). 한편,
[9][10]에서 제안된 노드 $i$ 의 확장 자아 네트워크는 기존 자 아 네트워크에 1-hop으로 연결되어 있는 노드들의 집합에서 그 노드들이 직접적으로 연결된 이웃 노드들 및 그들 사이 의 간선들까지 포함하여 결국 이전 절에서 제안한 $\mathrm{FoF}$ 개 념이 도입된 $S N_{i}$ 와 동일한 네트워크이다 (Fig. 3. (b) 참조). 이러한 확장 자아 네트워크는 DTN에 존재하는 모든 노드 들로 이루어진 전체 사회관계망에서 노드 $i$ 를 중심으로 한 부분 네트워크이며 각각의 노드가 자신망의 확장 자아 네트 워크를 구축하여 유지가 가능하다. 노드 $i$ 의 확장 자아 네트 워크가 구성되면 이를 이용하여 노드 $i$ 는 자신의 확장 매개 중심도 $C_{B}(i)$ 를 다음 식 (3)을 이용하여 매 단위시간 마다 산출한다[9, 10].

$$
C_{B}(i)=\sum_{\substack{s \neq i \neq t \in V_{X}, s<t}} \frac{\rho_{s t}(i)}{\rho_{s t}}
$$

위 식 (3)에서 $V_{X}$ 는 확장 자아 네트워크에 속한 노드의 집합이며 $\rho_{s t}$ 는 노드 $s$ 와 $t$ 사이의 최단경로 (shortest path) 개수이며, $\rho_{s t}(i)$ 는 노드 $s$ 와 $t$ 사이의 최단경로 중에서 노드 $i$ 를 통과하는 것들의 개수이다.

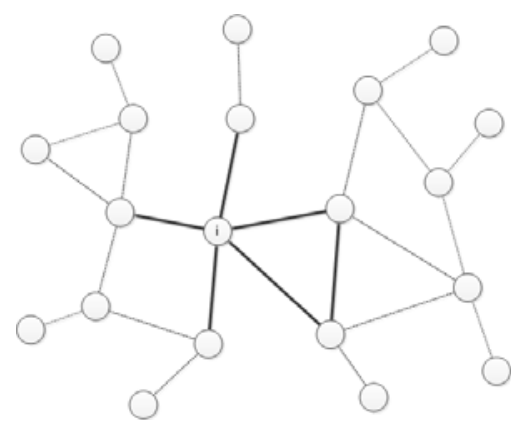

(a) Ego Network of Node $i$

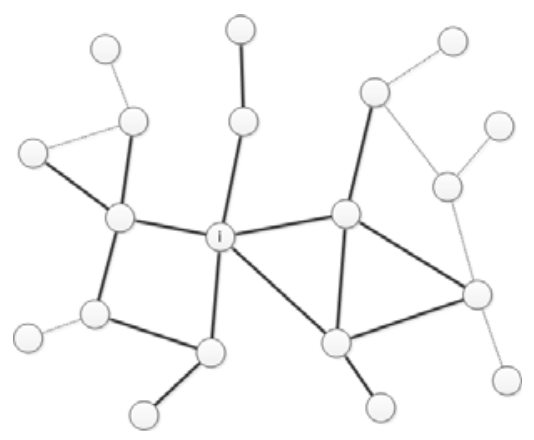

(b) Expanded Ego Network of Node $i\left(=S N_{i}\right)$

Fig. 3. Ego Network and Expanded Ego Network of Node $i$

\section{3 메시지 전달 전략}

앞서 설명한 것처럼, 임의의 노드 $i$ 는 매 단위 시간마다 1) 이전에 최소한 한번 이상 접촉했던 임의의 노드 $j$ 에 대해 가중치 $W_{i e g h} t_{i, j}$ 값을 갱신하고, 2) 자신의 사회관계망인 $S N_{i}$ 를 갱신하며, 3 ) 확장 자아 매개 중심도 $C_{B}(i)$ 을 갱신한다. 
이러한 정보를 통해 자신이 전달받은 메시지에 대해 그 메 시지를 목적지 노드까지 전달하는 전략을 세우게 된다. 본 절에서는 그 전략을 설명한다.

1) 가중치(Weight)를 활용한 기본적인 메시지 전달 전략 임의의 두 노드 $i$ 와 $j$ 사이에 접촉 한 횟수와 접촉 시간 이 길수록 가중치 $W_{e g h t}$ 값은 커지며 좀 더 친밀한 관계 라고 할 수 있다. 본 논문에서는 기본적으로 Friendship Routing에서 제안된 기법과 유사하게 이러한 가중치를 활용 하여 메시지를 중계할 노드를 선택한다. 즉, Fig. 4. 와 같이 노드 $i$ 가 노드 $j$ 와 만났을 경우 전달해야할 메시지의 목적 지가 노드 $k$ 라면, 다음과 같은 조건이 만족할 때 노드 $i$ 는 노드 $j$ 에게 해당 메시지를 전달한다.

$$
\text { Weight }_{j, k}>\text { Weight }_{i, k}
$$

즉, 노드 $j$ 가 산출한 노드 $k$ 와의 $W_{e i g h t}$ 가 노드 $i$ 가 산 출한 노드 $k$ 와의 Weight $_{i, k}$ 보다 클 경우 해당 메시지를 노드 $j$ 에게 전달한다.

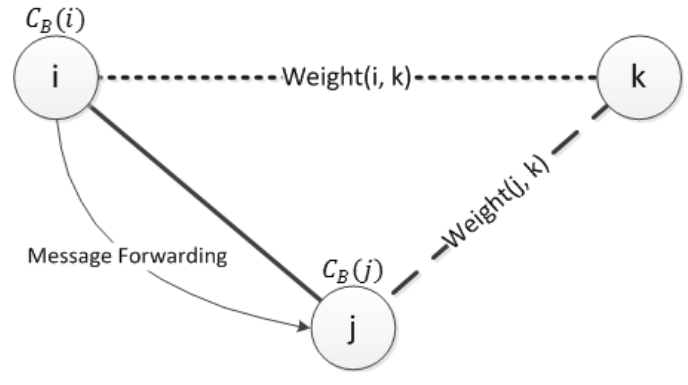

Fig. 4. Forwarding message strategy: Weight $_{i, k}>$ Weight $_{i, k}$ or $C_{B}(j)>C_{B}(i)$

2) 확장 자아 매개 중심도를 활용한 메시지 전달 효율 향상 전략

한편, 본 논문에서는 가중치만을 활용하는 Friendship Routing[6] 과는 달리 메시지 전달 효율을 높이기 위해 확장 매개 중심 도 함께 이용한다. 어떤 노드는 접촉하는 노드가 제한적일 수 있거나, 다른 노드와의 접촉횟수가 적고 접촉 시간도 짧 을 수 있다. 이럴 경우 그 노드는 다른 노드들과의 가중치 가 매우 적을 것이다. 만약 이러한 사회관계성이 매우 낮은 노드에게 메시지를 보낸다고 가정하면, 그 메시지를 전달해 야 할 노드 입장에서 해당 목적지 노드와의 가중치가 자신 이 지니고 있는 가중치보다 큰 노드를 발견할 가능성이 매 우 낮다. 예를 들어, Fig. 4. 에서 노드 $k$ 가 사회관계성이 매 우 낮은 노드이면서 노드 $i$ 가 전달해야 할 메시지의 목적지 노드라고 가정하자. 이 때, 노드 $i$ 입장에서 $W_{e i g h t} t_{i, k}$ 보다 더 큰 가중치 $W_{e i g h t}$ 를 지닌 임의의 노드 $j$ 를 만나기가 쉽지 않으며, 이러한 경우 메시지의 TTL (Time to Live) 값에 의해 해당 메시지는 목적지에 도달하기 전에 소멸될 확률이 크다.

이와 같은 상황이 자주 발생하는 것을 방지하기 위해 본 논문에서는 임의의 노드 $i$ 가 목적지 노드 $k$ 에 메시지를 전 달하려고 하면서 임의의 노드 $j$ 를 만났을 때, 조건식 (4)가
만족하지 않더라도 다음의 조건식 (5)가 만족하면 노드 $i$ 는 메시지를 노드 $j$ 에게 전달한다.

$$
C_{B}(j)>C_{B}(i)
$$

즉, 상대방 노드 $j$ 의 확장 매개 중심도 값이 자신의 확장 매개 중심도 보다 크다면, 자신보다 노드 $j$ 가 보다 사회관 계성이 높다는 것을 나타낸다. 이러한 사회관계성이 높은 노드 $j$ 에게 메시지를 전달하면 결국 미래에 목적지 노드 $k$ 에 대한 가중치가 높은 임의의 노드를 그 노드 $j$ 가 만날 확 률이 높을 것이므로, 이와 같은 전략은 전체적으로 메시지 전달 효율을 높여줄 것이다.

3) 메시지 전달 횟수 감소 전략

본 논문에서는 메시지의 무분별한 전달을 막고 특정 조건 에 대해서는 자신의 버퍼에서 메시지를 삭제하면서 중계 노 드에게 그 메시지를 전달하는 방법을 활용하여 전체적으로 메시지 전달 효율성을 높이는 기법을 제안한다.

임의의 노드 $i$ 가 목적지 노드 $k$ 까지 전달해야할 메시지 를 자신의 버퍼에 가지고 있으면서 다른 노드 $j$ 를 만났을 때 메시지 전달 조건 식 (4) 또는 (5)가 만족되면 해당 메시 지를 노드 $j$ 에게 전달한다. 이 때, 노드가 통신범위에 있을 때 메시지의 전송 충돌이 없고 항상 성공한다고 가정한다. 그리고, 노드 $i$ 는 자신의 사회관계망에 포함된 모든 노드들 에 대한 목적지 노드 $k$ 와의 모든 가중치 값들 보다 노드 $j$ 가 지닌 $W_{e i g h t}$ 가 크다면 해당 메시지를 자신의 버퍼에서 삭제하여 이후에는 해당 메시지에 대한 전달 과정에 참여하 지 않는다. 즉, 이후 해당 메시지의 전달 책임은 자신의 이 웃 중에서 노드 $k$ 와의 가중치가 가장 높은 노드 $j$ 에게 위임 하도록 만든다.

표 2는 지금까지 설명한 메시지 전달 전략에 대한 종합적 인 알고리즘을 제시한다.

Table 2. The proposed algorithm for a message forwarding when node $i$ tries to deliver the message to the destination node $k$

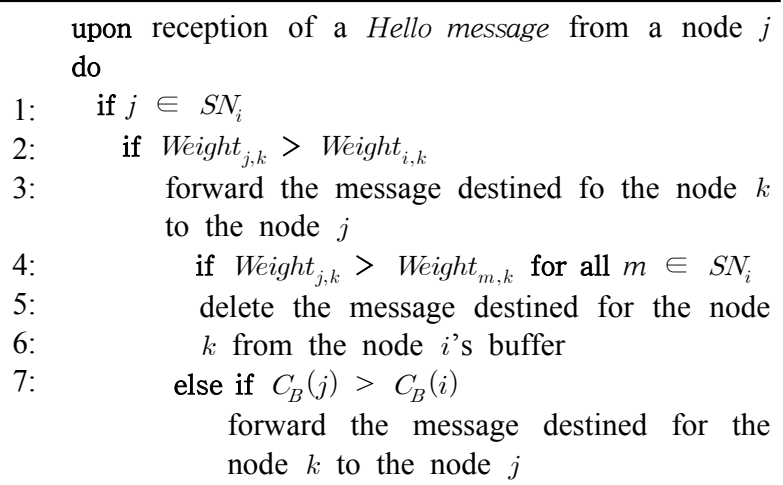

\section{4. 실험 및 분석}

본 장에서는 시뮬레이터를 구현하여 본 논문에서 제안하 는 라우팅 기법과 기존에 제안되었던 Epidemic Routing 및 
Friendship Routing의 성능을 비교 분석한 내용을 제시한다. 성능 분석 메트릭 (Metrics)로는 대부분의 DTN 라우팅 관 련 논문들에서 활용하는 1)메시지 전달 성공률, 2)메시지 전 달 비용, 3)메시지 전달 효율을 선정하였다.

\section{1 실험 환경}

본 논문에서 구현한 시뮬레이션 실험 환경은 표 3 과 같 다. 시뮬레이션이 시작되면 각 노드는 미리 설정된 이동성 모델에 따라 이동을 시작하며 다른 노드들과 서로 통신 반 경에 들어와 접촉을 하게 된다. 이후 접촉 윈도우 크기 $\left(W_{s}\right.$ $=600$ 초)에 해당하는 시간이 지나면 임의의 노드들은 일정 크기의 메시지를 지속적으로 생성하여 임의의 다른 노드를 목적지로 정하고 실시간으로 접촉하는 다른 노드들에게 전 달을 시도한다. 메시지가 라우팅 되면서 각 메시지는 목적 지까지 성공적으로 도달하거나 TTL 시간이 지날 때까지 목 적지에 도달하지 않으면 자동으로 소멸된다. 총 1000 개의 메시지가 생성된 후 모든 메시지가 목적지에 도달하거나 소 멸되면 시뮬레이션이 종료 된다. 실험 결과는 각 TTL 값마 다 총 10 회씩 실험하였으며 전체 실험값들의 평균을 구하여 실험 결과로 제시하였다.

Table 3. Experimental Environment

\begin{tabular}{c|c}
\hline Area Size $(\mathrm{m})$ & $1000 \times 1500$ \\
\hline Number of Nodes & $25,50,75$ \\
\hline Communication Range $(\mathrm{m})$ & 3 \\
\hline Moving Speed $(\mathrm{m} / \mathrm{s})$ & $0.5,1.0,1.2$ \\
\hline Contact Window Size $\left(W_{s}\right.$, second) & 600 \\
\hline TTL (second) & $60,120,180,240,300,360$ \\
\hline Threshold $\left(T_{h}\right)$ & 0.01 \\
\hline Number of Messages & 1000 \\
\hline
\end{tabular}

\section{2 실험 결과}

Fig 5는 TTL의 변화에 따른 메시지 전달 성공률을 보여 준다. 메시지 전달 성공률은 시률레이션이 진행되는 동한 생성된 1000개의 메시지 중 목적지 노드로 성공적으로 전달 된 메시지의 비율로 정의된다. 그림에서 알 수 있듯이 각 라우팅 기법들은 TTL의 크기가 증가 할수록 메시지 전달 성공률이 증가하는 것을 볼 수 있다. 즉 메시지의 생존시간 이 길어질수록 각 메시지가 목적지 노드까지 전달될 확률이 높아지는 것을 확인할 수 있다. 한편, 본 논문에서 제시하는 라 우팅 기법은 비교 대상인 Epidemic Routing 및 Friendship Routing 기법보다 메시지 전달 성공률 면에서 성능이 높지 는 않고 Friendship Routing 기법과 거의 유사하거나 조금 낮은 성능을 보인다. 그 이유는 본 논문에서 구성하는 사회관 계망에 포함되는 노드의 수는 기존 Friendship Routing 기법 에서 제시하는 사회관계망에 포함되는 노드 수보다 줄어들 며 사회관계망에 포함된 노드들만이 접촉을 하였을 때 메시 지 전달 대상으로 활용되기 때문이다. 하지만 Epidemic Routing처럼 접촉하는 모든 노드에게 메시지를 복사한다면 당연히 메시지 전달 성공률이 높아지겠지만 전체 노드에 걸 리는 메시지 처리 오버헤드와 비용이 매우 높아진다. 이처 럼 단순히 임의의 메시지를 목적지 노드까지 전달하는 것이
아니라 최대한 목적지에 도달시키면서도 메시지 전달 비용 을 줄이는 것이 본 논문의 연구 목표이다.

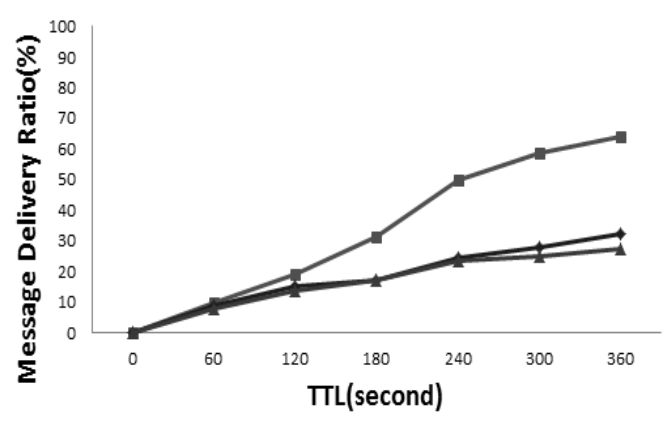

(a) Number of nodes $=25$

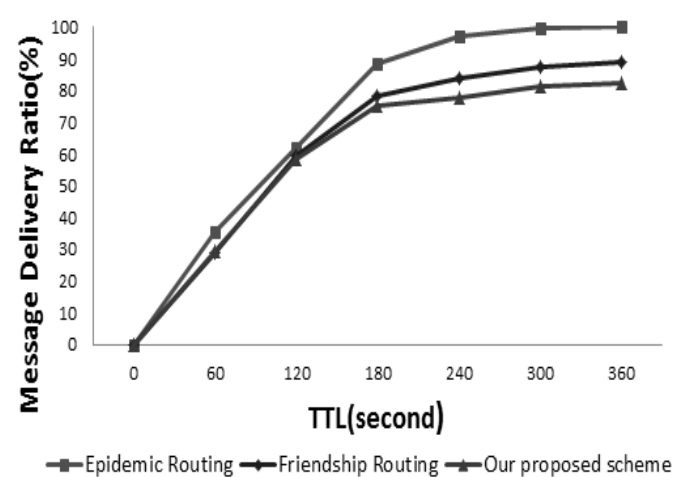

(b) Number of nodes $=50$

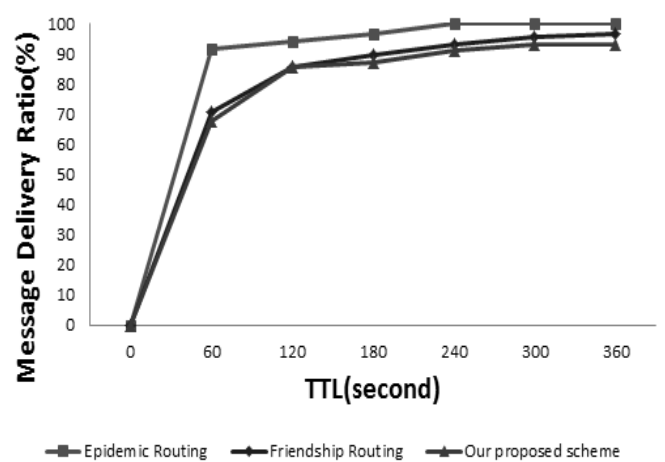

(c) Number of nodes $=75$

Fig. 5. Message Delivery ratio varying TTL (Time to Live) (Number of messages $=1000$, Threshold $\left(T_{h}\right)=0.1$ )

Fig 6은 TTL의 변화에 따른 메시지 전달 비용을 비교분 석하여 보여준다. 메시지 전달 비용은 시뮬레이션 수행시간 동안 생성된 모든 메시지들의 총 전달 횟수를 생성된 메시 지의 개수로 나눈 값을 의미한다. 그림에서 알 수 있듯이 Epidemic Routing은 메시지의 무분별한 복사 과정 때문에 매우 높은 메시지 전달 비용을 보이고 있음을 알 수 있다. 또한, TTL이 증가함에 따라 메시지 전달 성공률과 비슷하 
게 메시지 전달 비용도 증가는 하지만 그 증가 속도는 비교 적 낮다는 것을 알 수 있다. 즉, 처음에는 적은 횟수의 전달 과정만으로도 대부분의 메시지가 목적지 노드까지 전달되지 만 어느 정도 시간이 흐른 이후에는 메시지를 전달하는 조 건인 수식 (4) 또는 (5)를 만족하는 노드를 접촉할 기회가 적어짐을 알 수 있다. 한편, 제안 기법의 메시지 전달 비용 이 Friendship Routing 방법보다도 낮음을 알 수 있다. 이는 메시지의 무분별한 전달을 막고 특정 조건에 대해서는 자신 의 버퍼에서 메시지를 삭제하는 3장의 '3.2-3). 메시지 전달 횟수 감소 전략'에 기인한다.

Fig 7은 TTL의 변화에 따른 메시지 전달 효율성에 대한 비교 분석 결과를 보여준다. 메시지 전달 효율성은 메시지 전달 비용 대비 메시지 전달 성공률로 정의된다. 그림에서 알 수 있듯이, 제안하는 라우팅 기법의 효율성이 가장 높음 을 알 수 있다. 제안하는 라우팅 기법은 Epidemic Routing

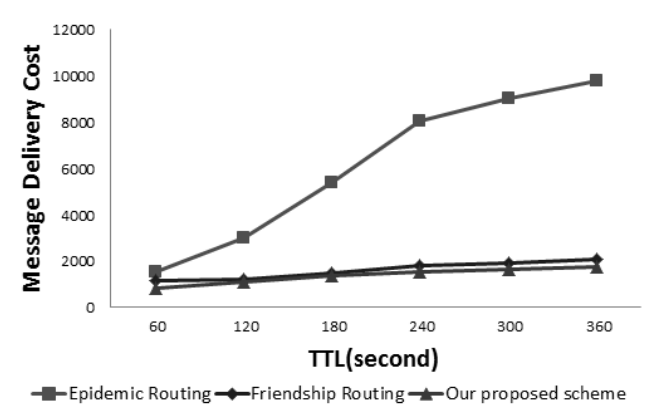

(a) Number of nodes $=25$

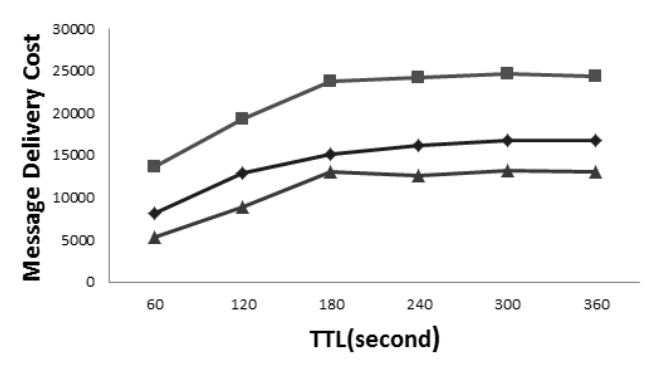

$\rightarrow$-Epidemic Routing $\rightarrow$ Friendship Routing $\rightarrow$ Our proposed scheme

(b) Number of nodes $=50$

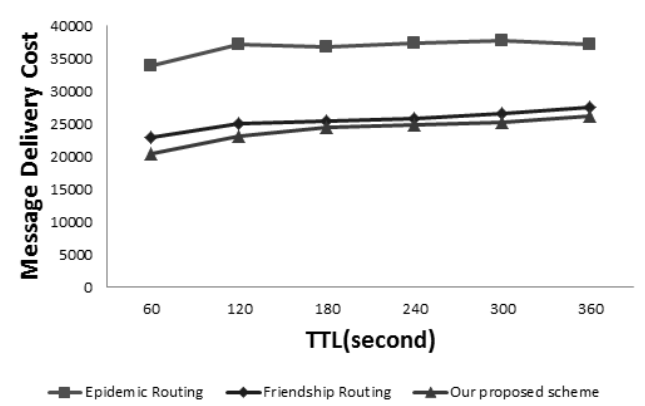

(c) Number of nodes $=75$

Fig. 6. Message Delivery Cost varying TTL (Time to Live) (Number of messages $=1000$, Threshold $\left(T_{h}\right)=0.1$ )
및 Friendship Routing과 비교하여 메시지 전달 성공률이 각각 평균적으로 약 $12.0 \%, 0.6 \%$ 정도만 감소하였지만, 메 시지 전달 비용 또한 평균적으로 약 $39.8 \%, 5.6 \%$ 씩 감소하 였다. 즉 메시지 전달 성공률의 감소보다 메시지 전달 비용 의 감소가 월등히 높은 것을 알 수 있다. 메시지 전달 효율 성이 높다는 것은 적은 횟수의 메시지 전달을 통해서도 많 은 메시지를 목적지 노드에게 전달할 수 있다는 것을 의미 하며 제안하는 기법은 이러한 메시지 전달 효율 면에서 뚜 렷한 우수성을 보인다.

\section{5. 결 론}

본 논문에서 우리는 노드들 간의 사회관계적 특성을 분석 하여 메시지 라우팅을 결정하는 새로운 방안을 제안하였다.

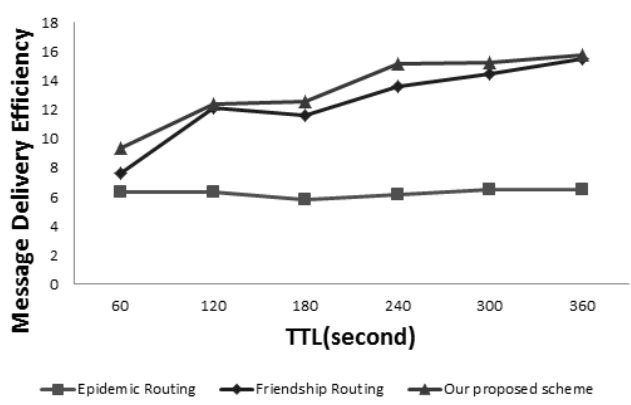

(a) Number of nodes $=25$

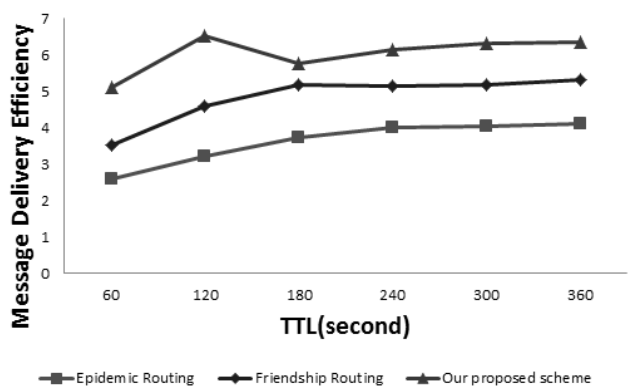

(b) Number of nodes $=50$

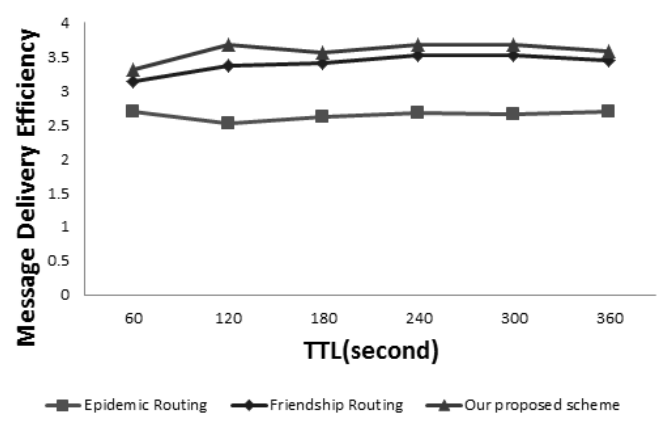

(c) Number of nodes $=75$

Fig. 7. Message Delivery Efficiency varying TTL (Time to Live) (Number of messages $=1000$, Threshold $\left(T_{h}\right)=0.1$ ) 
특히, 노드간의 과거 접촉 기록을 활용한 가중치 정보뿐만 아니라 확장 자아 매개 중심도를 이용하여 메시지를 목적지 노드까지 전달하는 효율적인 라우팅 기법을 제안하였다. 본 논문에서는 메시지 전달 성공률, 메시지 전달 비용, 메시지 전달 효율성이라는 성능지표를 기준으로 기존에 잘 알려진 Epidemic Routing 및 Friendship Routing과 시률레이션을 통해 성능을 비교하였다. 비교 분석 결과 제안하는 라우팅 기법은 적은 횟수의 메시지 전달만을 통하여 Friendship Routing과 비슷한 정도의 메시지 전달 성공률을 보임을 알 수 있었고 전반적으로 메시지 전달 효율이 높음을 알 수 있 었다. 향후에는 전통적인 사회관계망 연구 결과에서 제시된 보다 많은 분석 기법을 DTN 라우팅 기법에 도입하여 메시 지 전달 효율성뿐만 아니라 메시지 전달 성공률까지도 높일 수 있는 DTN 라우팅 기법을 개발할 예정이다.

\section{참 고 문 헌}

[1] F. Warthman, "Delay-Tolerant Networks(DTNS): A tutorial," Warthman Associates, Mar., 2003.

[2] M. R. Schurgot, C. Comaniciu, and K. Jaffres-Runser. "Beyond traditional DTN routing: social networks for opportunistic communication." Communications Magazine, IEEE 50.7 pp.155-162. Jul., 2012.

[3] A. Vahdat and D. Becker, "Epidemic Routing for Partially Connected Ad Hoc Networks," Technical Report CS-200006, Duke University, 2000.

[4] A.Lindgren, A. Doria, and O. Schelen. "Probabilistic routing in intermittently connected networks," Service Assurance with Partial and Intermittent Resources. Springer Berlin Heidelberg, pp.239-254. 2004.

[5] P.Hui, J. Crowcroft, and E. Yoneki. "Bubble rap: social-based forwarding in delay tolerant networks." Proceedings of the 9th ACM international symposium on Mobile ad hoc networking and computing. ACM, 2008.

[6] Bulut, Eyuphan, and Boleslaw K. Szymanski. "Friendship based routing in delay tolerant mobile social networks," Global Telecommunications Conference (GLOBECOM 2010), 2010 IEEE. IEEE, 2010.

[7] L. Tang and H. Liu, "Community Detection and Mining in Social Media," Synthesis Lectures on Data Mining and Knowledge Discovery, Vol.2, No.1, 2010.

[8] S. Wasserman and K. Faust. "Social Network Analysis: Methods and Applications," Cambridge University Press, 1994.

[9] J.-g. Shon, Y.-h. Kim, Y.-H. Han, "Local Information-based Betweenness Centrality to Identify Important Nodes in Social Networks," KIPS Transactions on Computer and Communication System, Vol. 02 No.05. pp.209 216, 2013.

[10] Y.-h. Kim, C.-M. Kim, Y.-H. Han, Y.-S. Jeong and D.-S. Park, "Betweenness of Expanded Ego Networks in Sociality-Aware Delay Tolerant Networks," Ubiquitous Information Technologies and Applications (LNEE, Proc. of CUTE 2012), Springer, pp.499-505, Dec., 2012.

[11] F. Li and J. Wu, "LocalCom: a community-based epidemic forwarding scheme in disruption-tolerant networks," Proc. IEEE Conf. Sensor, Mesh and Ad Hoc Communications and Networks, pp.574-582, June, 2009.

[12] M. Everett, S. P. Borgatti, "Ego Network Betweenness," Social Networks, Vol.27, No.1, pp.31-38, Jan., 2005.

[13] F. Odella, "Using Ego-networks in Surveys: Methodological and Research Issues," In Proceedings of International Conference on Network Science, May, 2006.

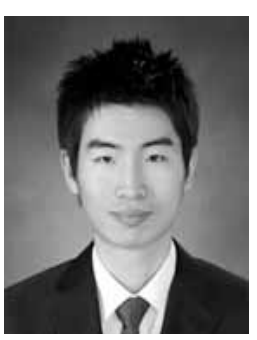

\section{김 찬 명}

e-mail :cmdr@koreatech.ac.kr

2009년 한국기술교육대학교 멀티미디어 공학과(학사)

2011년 한국기술교육대학교 컴퓨터공학과 (석사)

2011년 현 재 한국기술교육대학교 컴퓨 터공학과 박사과정

관심분야: 사회관계망 분석, 지연 감내 네트워크

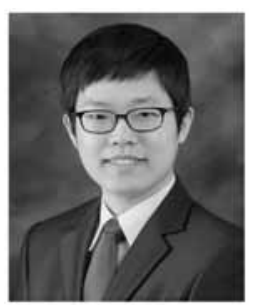

강 인 석

e-mail : iseka@koreatech.ac.kr

2011년 한국기술교육대학교 컴퓨터공학부 (학사)

2013년 한국기술교육대학교 컴퓨터공학과 (석사)

2013년 현 재 삼성전자 무선사업부 연구원 관심분야: 사회관계망 분석, 지연 감내 네트워크, 로봇 네트워크

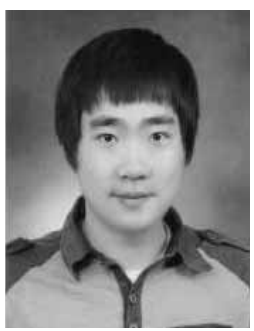

\section{오 영 준}

e-mail : youngjn@koreatech.ac.kr

2009년 나사렛대학교 정보통신학과 (이학사)

2011년 한국기술교육대학교 전기전자 공학과(석사)

2011년 현 재 한국기술교육대학교 컴퓨터 공학과 박사과정

관심분야: Ubiquitous computing, $\mathrm{WSN}, \mathrm{Ad}-\mathrm{hoc}$ network, 차세 대이동통신기술, Wireless SoC

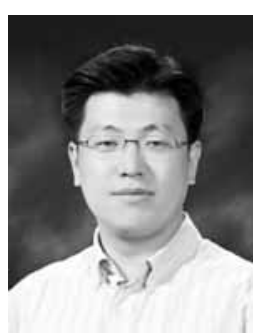

한 연 희

e-mail : yhhan@koreatech.ac.kr

2002년 고려대학교 대학원 컴퓨터학과

(이학박사)

2002년 2006년 삼성종합기술원 전문연구원

2006년 현 재 한국기술교육대학교 컴퓨 터공학부 교수

2005년 현 재 한국정보통신기술협회(TTA) IT 국제 표준화 전문가

관심분야: 이동 컴퓨팅, 센서 네트워크, 사회관계망 분석 